\title{
Influence of saddle height and exercise intensity on pedalling asymmetries in cyclists
}

\section{Influência da altura do selim e intensidade do exercício sobre assimetrias na pedalada de ciclistas}

\author{
Fernando Diefenthaeler ${ }^{1}$ \\ Joscelito 0 Berneira $^{1}$ \\ Vanderson L Moro ${ }^{1}$ \\ Felipe P Carpes²
}

\begin{abstract}
Pedaling asymmetries quantified during stationary cycling, when cyclist body positioning and intensity remain unchanged, may not fully reproduce the training and competition situations, in which cyclists experience different intensities and may opt for different saddle positioning aiming at power output optimization. Previous studies showed that torque and power can be asymmetric in cyclists. It is not clear whether changes in saddle height and exercise intensity may affect asymmetries. The aim of the present study was to determine pedaling asymmetries during cycling at different saddle heights and different exercise intensities. Twelve competitive cyclists performed an incremental maximal test, a constant-load ("heavy" intensity domain), and a Wingate test. Constant load and the Wingate tests were repeated using three different saddle heights (reference and lower or higher by $2.5 \%$ of the distance from the pubic symphysis to the ground). Crank torque was recorded throughout the pedaling cycle. Asymmetry (higher torque for the preferred limb) was found in all saddle heights $(\mathrm{p}<0.001)$ in both intensities. Asymmetry index was similar across the saddle positions $(p>0.05)$ in both intensities. Our results suggest that asymmetric cyclists present a consistent pattern regardless of small changes in the saddle height or in exercise intensity. For practical implication, cyclists producing asymmetric torque may be adapted to this condition so they are continuously exposed to asymmetric effort and overload on the lower limbs.
\end{abstract}

Key words: Exercise test; Posture; Cycling; Biomechanics; Injury.

Resumo - Assimetrias na pedalada quantificadas durante o ciclismo estacionário, em que a postura do ciclista e a intensidade não mudam significativamente, podem não reproduzir situaçóes de treino e competiçóes em que os ciclistas experimentam diferentes intensidades e optam por mudar a postura no selim para otimização da potência. Estudos prévios mostraram assimetrias no torque e potência de ciclistas. Não é claro se mudanças na posição do selim e intensidade afetam essas assimetrias. O objetivo do presente estudo foi determinar as assimetrias na pedalada durante o ciclismo em diferentes alturas de selim e diferentes intensidades de esforço. Doze ciclistas competitivos realizaram um teste incremental máximo, um teste de carga constante (dominio severo) e um teste de Wingate. Os testes de carga constante e Wingate foram repetidos usando três alturas de selim (referência e 2,5\% abaixo ou acima da referência, que foi medida pela distância da sinfise púbica até o solo). O torque gerado no pedivela foi medido durante todo o ciclo de pedalada. Assimetrias (maior torque na perna preferida) foram encontradas em todas as alturas de selim $(p<0,001) \mathrm{em}$ ambas as intensidades. $O$ indice de assimetria foi similar em todas as alturas de selim $(p<0,05)$ em ambas as intensidades. Os resultados sugerem que ciclistas assimétricos apresentam um padrão consistente independente de pequenas mudanças na posição do selim ou intensidade do exercício. Como implicação prática, ciclistas produzindo torque assimétrico podem estar adaptados a esta condição e sendo continuamente expostos a esforços e sobrecargas assimétricas nos membros inferiores.

Palavras-chave: Teste de esforço; Postura; Ciclismo; Biomecânica; Lesão.
1 Federal University of Santa Catarina. Biodynamics Research Group. Laboratory of Biomechanics. Florianópolis, SC. Brazil.

2 Federal University of Pampa. Applied Neuromechanics Research Group. Laboratory of Neuromechanics. Uruguaiana, RS. Brazil.

Received: 17 January 2016 Accepted: 04 July 2016 


\section{INTRODUCTION}

Studies on pedaling asymmetries consider a constant body positioning sustained during short bouts of exercise mostly at fixed intensity. Although such investigations made a major contribution to the study of leg asymmetries in cycling, they did not consider the influence of changing saddle position as representative of small adjusts that cyclists do to optimize power output during a training or competition ${ }^{1-7}$. Small changes in saddle position are observed during cycling practice. During cycling to exhaustion, cyclists change their sitting position (i.e. more forward position) when performing at high levels of effort ${ }^{8,9}$. When exercising at supra-maximal efforts, altering the saddle position affects mean power output ${ }^{10,11}$, which is not observed at sub-maximal intensities ${ }^{12}$. Another source of deviations in performance is the influence of changing saddle height on force-length muscle relations and therefore force output ${ }^{13,14}$. One could argue that specific saddle positions could result in specific adaptation in length muscle relations, as observed for rectus femoris torque in response to different range of motions experienced by cyclists and runners ${ }^{15}$. Surprisingly, the question whether changes in saddle height position could influence the magnitude of pedaling asymmetries seems not to be addressed by previous studies. Pedaling asymmetry is often analyzed in a single saddle position, which limits application of this information for a specific race, for example, when cyclists are free to vary, even if by small amounts, the saddle position (i.e. during climbing and time-trials).

To address the effects of changing saddle height and exercise intensity on the magnitude of pedaling asymmetries, trained cyclists were evaluated assuming different saddle heights. The intensity of the exercise was also varied to determine effects of sub-maximal and supra-maximal intensity on pedaling asymmetries. Since cycling is an activity in which the motor pattern of pedaling is extensively repeated, the consistency of asymmetries during altered saddle positioning could suggest the occurrence of asymmetric performance in training and competition.

\section{METHODOLOGICAL PROCEDURES}

\section{Participants}

Twelve cyclists currently competing at regional and national level took part in this investigation. The mean and standard deviation age, height, body mass, body mass percentage, cycling experience, cycling training volume, maximal oxygen uptake $\left(\mathrm{VO}_{2} \max \right)$, and maximal power were $31.7 \pm 5.9$ years, $176.1 \pm 6.1 \mathrm{~cm}, 73.8 \pm 6.6 \mathrm{~kg}, 10.8 \pm 2.9 \%, 3.9 \pm 4.1$ years, $217.5 \pm$ $103.2 \mathrm{~km} /$ week, $56.8 \pm 3.8 \mathrm{ml} \cdot \mathrm{kg}^{-1} \cdot \mathrm{min}^{-1}$, and $316.4 \pm 35.6 \mathrm{~W}$, respectively. All participants were injury-free at the time of participation and signed an informed consent form before the start of the study, which was approved by the local Committee for Ethics in Research with Humans (protocol number 065/06) and in accordance with the Helsinki declaration. 


\section{Experimental Procedures}

Tests were performed in four different days, with $48 \mathrm{~h}$ interval between each. On the first day, participants completed anthropometric assessments, performed a maximal incremental exercise test, and a familiarization trial to the Wingate test. The incremental test was used to determine parameters related to aerobic capacity of the athletes. The expired respiratory gases were collected and analyzed using a Quark PFTergo metabolic system (Cosmed, Rome, Italy) calibrated in accordance with the manufacturers' instructions. $\mathrm{VO}_{2}$ max was defined as the highest oxygen uptake $\left(\mathrm{VO}_{2}\right)$ recorded over a $30 \mathrm{~s}$ period. Ventilatory threshold (VT) was determined using the ventilatory equivalent method $^{16}$. Familiarization with Wingate included a $15 \mathrm{~s}$ maximal trial. On testing days 2-4, participants performed a $6 \mathrm{~min}$ constant-load test followed by a repetition of the Wingate anaerobic test. Constant load and Wingate tests were repeated at different saddle heights (one height per day). The order of the saddle heights tested was randomized. The standard saddle position was defined as the individual preferential position assumed by the participants during training and competitions ${ }^{14}$. This measure was taken from the own cyclist's bicycle. The two additional saddle heights tested were obtained by changing saddle up or down by $2.5 \%$ of the distance from the pubic symphysis to the ground ${ }^{17}$. All tests were performed in an electromagnetic braked cycle ergometer (Excalibur Sport ${ }^{\circledR}$, Lode, Netherlands). Sitting position was individually adjusted for each participant to correspond to their own bicycle with regards to horizontal position, saddle and handlebar heights.

\section{Incremental test}

The incremental test started at $100 \mathrm{~W}$, with $30 \mathrm{~W}$ increments every $3 \mathrm{~min}$ until exhaustion ${ }^{18}$. Preferred cycling cadence was determined during the two initial stages of the test and thereafter participants were instructed to maintain that cadence throughout the test. Exhaustion was defined as the moment in which the participant could not maintain the cycling cadence anymore $^{18}$. All participants were equally and strongly encouraged throughout the tests to perform to the best of their ability.

\section{Constant-load test}

The intensity of the constant-load test was determined using physiological parameters according to equation 1 , and ensuring that all participants were exercising in the "heavy" intensity domain ${ }^{19}$.

$$
\Delta 50 \%=V O_{2} @ V T+\left[0.5 \cdot\left(V O_{2 M A X}-V O_{2} @ V T\right)\right]
$$

Where: $\Delta 50 \%$ corresponding to $50 \%$ of the difference between maximum oxygen uptake $\left(\mathrm{VO}_{2} \max \right)$ and oxygen uptake at ventilatory threshold ( $\left.\mathrm{VO}_{2} @ \mathrm{VT}\right)$.

Before the start of the constant-load test, cyclists warmed up for $4 \mathrm{~min}$ at $30 \mathrm{~W}$. Intensity was subsequently adjusted to $\Delta 50 \%$ and sustained for $6 \mathrm{~min}$. An active recovery interval of 4 min cycling at $30 \mathrm{~W}$ followed the 
constant-load test. Participants cycled at their preferred cadence throughout the test. After the test, participants were allowed to rest for $10 \mathrm{~min}$ before start the Wingate test ${ }^{20}$.

\section{0-s Wingate anaerobic test}

For the Wingate test, athletes were instructed to remain seated on the saddle and to perform at maximal effort throughout the test ${ }^{11}$. The load (resistance) used during the Wingate test was equivalent to $7.5 \%$ of the participant individual body mass ${ }^{21}$. Participants were verbally encouraged to perform at maximal effort during the entire test. The test was followed by 3 min of active recovery cycling at $50 \mathrm{~W}$.

\section{Torque analyses}

The preferred lower limb was verified using the revised version of Waterloo Inventory ${ }^{22}$. Crank torque was measured every two degrees throughout the pedaling cycle (0-360 ) using instrumented crank-arms (LEM - Excalibur Sport $^{\oplus}$, Lode, Netherlands). Peak torque for each limb was defined as the highest value measured between $0^{\circ}$ and $180^{\circ}$ (propulsive phase) of the pedaling cycle. The asymmetry index was calculated using equation $2^{23}$, which provides the magnitude and direction of bilateral asymmetry in relation to the preferred limb.

$$
\mathrm{AI} \%=\left(\frac{\mathrm{p}-\mathrm{NP}}{\mathrm{p}}\right) \times 100
$$

Where: Al means the percent asymmetry index considering the ratio between peak torque measurements taken for the preferred (P) and non-preferred (NP) limbs.

\section{Statistics}

Data are presented as mean and standard deviation. Data normality, sphericity and homogeneity of variances were tested using the ShapiroWilk, Mauchly and Levene tests, respectively. Peak crank torques were compared between lower limbs and saddle heights using analysis of variance (ANOVA) for mixed linear models (2 lower limbs x 3 saddle heights) for each intensity test (constant load and Wingate). Bonferroni correction for multiple comparisons was performed when necessary. For a saddle height effect and repeated-measures ANOVA with Bonferroni post-hoc was used to compare the different saddle heights.

The asymmetry index was compared between the three saddle heights by repeated-measures ANOVA and Bonferroni post-hoc. Student t-test was applied to compare the asymmetry index between the constant-load and Wingate tests. All statistical tests were performed using SPSS for Windows (SPSS 17.0, USA) and a significance level of $\alpha=0.05$ was adopted. Effect size (ES) was calculated as Cohen's d to compare the magnitude of differences. The criteria to interpret the magnitude of the ES were 0.0-0.2 trivial, 0.2-0.6 small, 0.6-1.2 moderate, 1.2-2.0 large and $>2.0$ very large ${ }^{24}$. 


\section{RESULTS}

In the constant-load test significant asymmetry in favor of the preferred limb was found for the three saddle heights $\left(\left[\mathrm{F}_{(1,55)}=16.83 ; \mathrm{p}<0.001\right] \mathrm{Co}^{-}\right.$ hen's $\mathrm{d}=0.8,1.1$, and 0.2 for reference, downward, and upward position, respectively) (Figure 1). The different saddle heights did not influenced peak torque produced by the preferred $\left.\left[\mathrm{F}_{(2,22)}=0.092 ; \mathrm{p}=0.913\right)\right]$ and nonpreferred $\left[\mathrm{F}_{(2,22)}=3.243 ; \mathrm{p}=0.58\right]$ limb.

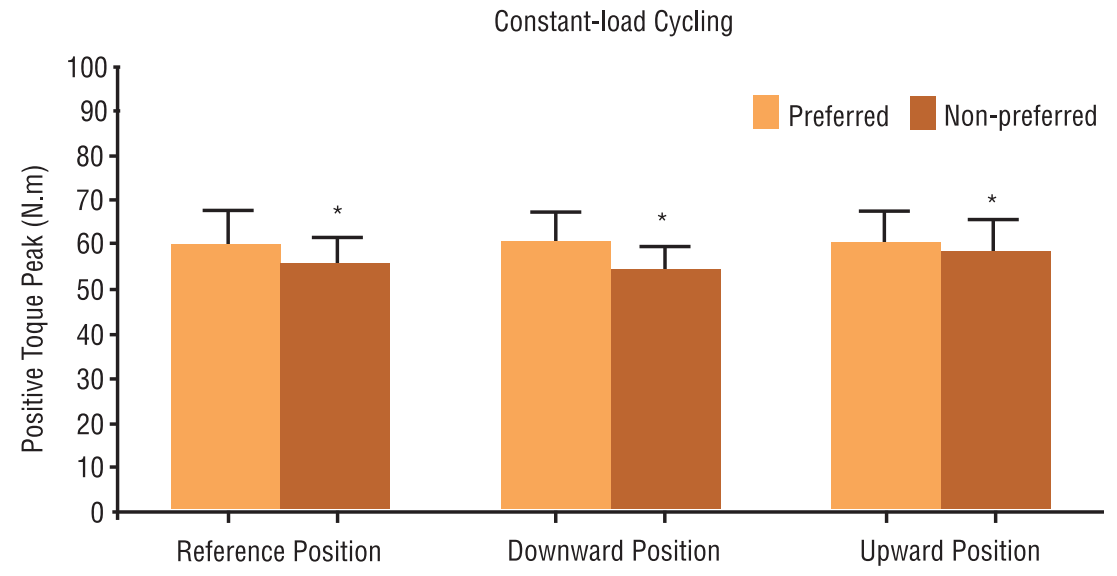

Figure 1. Mean and standard-deviation peak torque for preferred and non-preferred lower limb for saddle in the reference, downward, and upward position in the constant-load cycling. *Difference between limbs $(p<0.05)$.

Also during Wingate test significant asymmetry in favor of the preferred limb was observed for all three saddle heights tested $\left(\left[\mathrm{F}_{(1,55)}=16.83\right.\right.$; $\mathrm{p}<0.001]$, Cohen's $d=0.9,1.4$, and 0.9 for reference, downward, and upward position, respectively (Figure 2). Peak torque during the Wingate test was similar between the three saddle heights for the preferred $\left[\mathrm{F}_{(2,22)}=0.928\right.$; $\mathrm{p}=0.410]$ and non-preferred limb $\left[\mathrm{F}_{(2,22)}=1.281 ; \mathrm{p}=0.298\right]$.

Wingate test $\quad$ Preferred Non-preferred

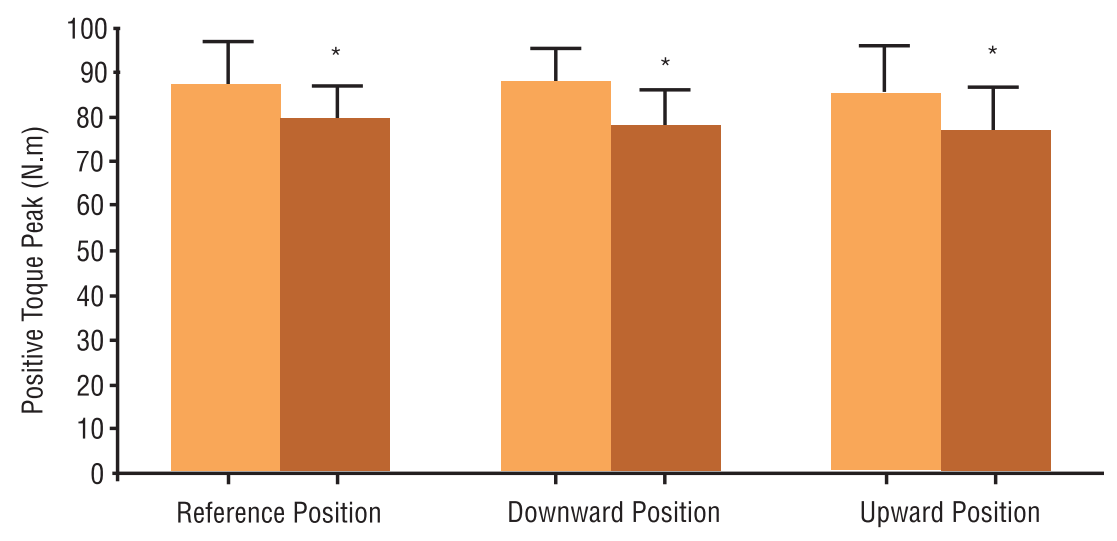

Figure 2. Mean and standard-deviation peak torque for preferred and non-preferred lower limb for saddle in the reference, downward, and upward position in the Wingate test. *Difference between limbs $(p<0.05)$.

The asymmetry index was similar between the two exercise intensities (Table 1), and it was not influenced by saddle height in the constant-load 
$\left[\mathrm{F}_{(2,22)}=1.548 ; \mathrm{p}=0.235\right]$ and Wingate test $\left[\mathrm{F}_{(2,22)}=0.4586 ; \mathrm{p}=0.6381\right]$. During the constant-load test, asymmetry index ES values were Cohen's $d=0.2$, 0.5 , and 0.6 for reference, downward, and upward position, respectively. During the Wingate test, asymmetry index ES values were Cohen's $\mathrm{d}=0.4$, 0.1 , and 0.2 , for reference, downward, and upward positions, respectively.

Table 1. Individual, mean and standard-deviation of the asymmetry index in the three saddle heights at two exercise intensities evaluated.

\begin{tabular}{lcccccc}
\hline \multicolumn{3}{c}{ Constant-Ioad } & \multicolumn{3}{c}{ Wingate } \\
\hline Subject & Reference & Downward & Upward & Reference & Downward & Upward \\
\hline 1 & 1.28 & -0.48 & -0.51 & 13.09 & 6.05 & 5.32 \\
2 & 7.82 & 10.57 & 1.54 & 5.86 & -3.13 & -7.25 \\
3 & 13.28 & 18.55 & 13.27 & 18.09 & 14.42 & 13.53 \\
\hline 4 & 15.89 & 18.16 & -30.27 & 8.57 & 12.90 & -15.22 \\
\hline 5 & -4.74 & -21.89 & 17.12 & -4.15 & 11.15 & 13.96 \\
6 & 17.19 & 15.62 & 16.22 & 13.91 & 10.85 & 14.08 \\
7 & -1.06 & 20.85 & -26.54 & 6.47 & 20.90 & 13.76 \\
8 & 11.17 & 10.32 & 9.11 & 8.57 & 11.16 & 9.71 \\
9 & -12.44 & 11.69 & 3.38 & -2.24 & 9.32 & 11.71 \\
10 & 18.34 & 14.71 & 5.28 & -1.06 & 18.99 & 19.74 \\
11 & 16.53 & 14.86 & 16.97 & 10.53 & 10.75 & 15.63 \\
12 & 17.88 & 9.49 & -8.73 & 19.82 & 9.88 & 16.09 \\
Mean & 8.43 & 10.20 & 1.40 & 8.12 & 11.10 & 9.26 \\
SD & 10.30 & 11.54 & 16.01 & 7.69 & 6.07 & 10.33 \\
\hline
\end{tabular}

\section{DISCUSSION}

Our main findings support the concept that pedaling asymmetry can be consistent across different saddle heights when cyclists performed at two different intensities. Our results are in accordance with previous reports showing asymmetries in crank torque are in favor of the preferred limb $\mathrm{im}^{3,6,7}$. The asymmetries observed across the different exercise intensities tested also elicited similar asymmetry indexes between trials with different saddle heights. From a practical perspective, our data suggest that cyclists may be subject to asymmetric performance and loading when performing at preferred saddle position, and also when small deviations from the reference saddle height are experienced.

The results suggested that pedaling asymmetry is present regardless of the saddle position tested. Even though former investigations suggest that changing saddle position might affect peak and mean power output ${ }^{10,11}$, few information is available concerning torque and torque asymmetry. Our results suggest that cyclists performing asymmetrically are highly consistent within their own pattern, which reinforces the possibility that they are also asymmetrical during training and competition.

The asymmetry index was similar between saddle heights at different exercise intensities, which suggest an asymmetric performance when pedaling at the reference position and even when small deviations from this position. Although this would suggest neuromuscular adaptation for force 
production, the magnitude of muscle activation when cycling at different conditions and intensities was symmetric in both cyclist and non-cyclists ${ }^{25,26}$.

A similar pedaling asymmetry was observed during both sub-maximal and maximal cycling trials. It has been suggested that torque asymmetry can be inversely associated with intensity during simulated time-trial competition ${ }^{6}$. However the results of the present study do not support the intensity effect reported. The differences in the outcomes between our study and the previous one ${ }^{6}$ may rely on the fact that while we used a constant sub-maximal intensity, Carpes et al. ${ }^{6}$ performed a simulated competition, in which participants were free to vary intensity during the trial.

An important question rising from the current results concerns the potential neuromuscular adaptations that might take place in asymmetric cyclists. To answer this question, a prospective or longitudinal study would be required. Furthermore, our results raise the question of whether correcting pedaling asymmetry can influence performance. Although not clear concerning an effect on performance, it was previously suggested that, among runners, any change in movement technique aiming at improve symmetry should be carefully conducted, since mechanical overload to muscles and joints increase injury risk through increased stress to these tissues $^{27,28}$. For cyclists, training the muscles that cross the hip joint could contribute to decreases or even avoids lower limb asymmetries ${ }^{5}$. It is important to mention that quantification of the index of effectiveness was not possible in our study, but such variable could significantly help to discuss implications of pedaling technique in regard of the asymmetries observed.

\section{CONCLUSION}

The results of the current study demonstrate that pedaling asymmetry in trained road cyclists can be consistent across different saddle heights and even at different cycling intensities. From a practical point of view, our data suggest that cyclists producing asymmetric torque may be adapted to this condition so they are continuously exposed to asymmetric effort and overload on the lower limbs.

\section{Acknowledgements}

The authors would like to thank the subjects who participated in this study and CNPq and Capes-Brazil for financial support

\section{REFERENCES}

1. Cavanagh PR, Petak KL, Shapiro R, Daly D. Bilateral asymmetry in work output during cycling ergometer pedaling. Med Sci Sports Exerc 1974;6(1):80-1.

2. Daly DJ, Cavanagh PR. Asymmetry in bicycle ergometer pedalling. Med Sci Sports Exerc 1976;8(3):204-8.

3. Sargeant AJ, Davies CT. Forces applied to cranks of a bicycle ergometer during oneand two-leg cycling. J Appl Physiol Respir Environ Exerc Physiol 1977;42(4):514-8.

4. Sanderson DJ. The influence of cadence and power output on asymmetry of force application during steady-rate cycling. J Hum Mov Stud 1990;19:1-9. 
5. Smak W, Neptune RR, Hull ML. The influence of pedaling rate on bilateral asymmetry in cycling. J Biomech 1999;32(9):899-11.

6. Carpes FP, Rossato M, Faria IE, Mota CB. Bilateral pedalling asymmetry during a simulated 40-km cycling time-trial. J Sports Med Phys Fitness 2007;47(1):51-7.

7. Carpes FP, Rossato M, Faria IE, Mota CB. Influence of exercise intensity on bilateral pedalling symmetry. Progress in motor control IV 2007;11(suppl):54-5.

8. Bini RR, Diefenthaeler F, Mota CB. Fatigue effects on the coordinative pattern during cycling: kinetics and kinematics evaluation. J Electromyogr Kinesiol 2010;20(1):102-7.

9. Bini RR, Senger DC, Lanferdini FC, Lopes ALC. Joint kinematics assessment during cycling incremental test to exhaustion. Isokinet Exerc Sci 2012;20(2):99-105.

10. Peveler WW, Pounders JD, Bishop PA. Effects of saddle height on anaerobic power production in cycling. J Strength Cond Res 2007;21(4):1023-27.

11. Peveler WW, Green JM. Effects of saddle height on economy and anaerobic power in well-trained cyclists. J Strength Cond Res 2011;25(3):629-33.

12. Bini RR, Diefenthaeler F, Carpes FP. Lower limb muscle activation during a $40 \mathrm{~km}$ cycling time trial: Co-activation and pedaling technique. Int SportsMed J 2011;12(1):7-16.

13. Too D. Biomechanics of cycling and factors affecting performance. Sports Med 1990;10(5):286-03.

14. Diefenthaeler F, Bini RR, Laitano OL, Guimaraes ACS, Nabinger E, Carpes FP, et al. Assessment of the effects of saddle position on cyclists' pedaling technique. Med Sci Sports Exerc 2006;38:S181.

15. Herzog W, Guimarães AC, Anton MG, Carter-Erdman KA. Moment-length relations of rectus femoris muscles of speed skaters/cyclists and runners. Med Sci Sports Exerc 1991;23(11):1289-96.

16. Reinhard U, Müller PH, Schmülling RM. Determination of anaerobic threshold by the ventilation equivalent in normal individuals. Respiration 1979;38(1):36-42.

17. Bini RR, Hume PA, Croft JL. Effects of Bicycle Saddle Height on Knee Injury Risk and Cycling Performance. Sports Med 2011;41(6):463-76.

18. Rossato M, Bini RR, Carpes FP, Diefenthaeler F, Moro AR. Cadence and workload effects on pedalling technique of well-trained cyclists. Int J Sports Med 2008;29(9):746-52.

19. Scheuermann BW, Hoelting BD, Noble ML, Barstow T. The slow component of O2 uptake is not accompanied by changes in muscle EMG during repeated bouts of heavy exercise in humans. J Physiol 2001;531(Pt 1):245-56.

20. Ferreira LF, Harper AJ, Townsend DK, Lutjemeier BJ, Barstow TJ. Kinetics of estimated human muscle capillary blood flow during recovery from exercise. Exp Physiol 2005;90(5):715-26.

21. Bar-Or O. The Wingate anaerobic test. An update on methodology, reliability and validity. Sports Med 1987;4(6):381-94.

22. Elias LJ, Bryden MP, Bulman-Fleming MB. Footedness is a better predictor than is handedness of emotional lateralization. Neuropsychologia 1998;36(1):37-43.

23. Chavet P. Lafortune MA, Gray JR. Asymmetry of lower extremity responses to external impact loading. Hum Mov Scie 1997;16(4):391-06.

24. Hopkins WG. Measures of reliability in sports medicine and science. Sports Med 2000;30(1):1-15.

25. Carpes FP, Mota CB, Faria IE. On the bilateral asymmetry during running and cycling A review considering leg preference. Phys Ther Sport 2010;11(4):136-42.

26. Carpes FP, Diefenthaeler F, Bini RR, Stefanyshyn D, Faria IE, Mota CB. Does leg preference affect muscle activation and efficiency? J Electromyogr Kinesiol 2010;20(6):1230-6.

27. Vagenas G, Hoshizaki TB. Evaluation of rearfoot asymmetries in running with worn and new running shoes. Int J Sport Biomech 1988;4(3):220-30.

28. Vagenas G, Hoshizaki TB. Functional asymmetries and lateral dominance in the lower limbs of distance runners. Int J Sport Biomech 1991;7(4):311-29.
CORRESPONDING AUTHOR

Fernando Diefenthaeler Universidade Federal de Santa Catarina

Campus Universitário Trindade Centro de Desportos, Laboratório de Biomecânica

Florianópolis/SC CEP: 88040-970

- Brasil

E-mail:fernando.diefenthaeler@ufsc.br 